INTER NATIONAL MONETARY FUND

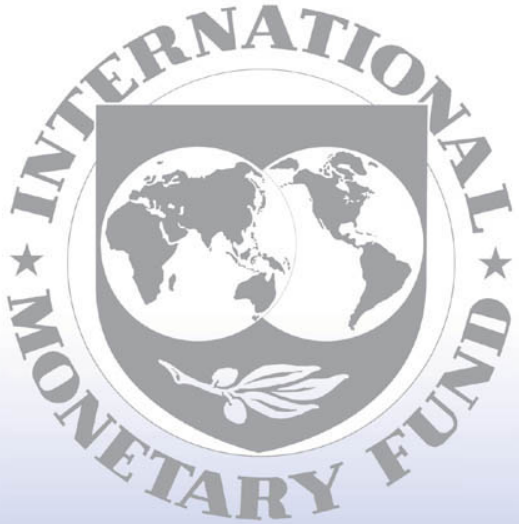

Staff

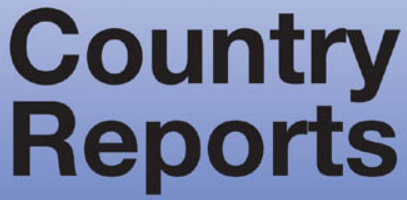




\title{
Costa Rica: Third and Final Review Under the Stand-By Arrangement —Staff Report; Press Release on the Executive Board Discussion; and Statement by the Executive Director for Costa Rica.
}

In the context of the Third and Final Review under the Stand-By Arrangement, the following documents have been released and are included in this package:

- $\quad$ The staff report for the Third and Final Review Under the Stand-By Arrangement, prepared by a staff team of the IMF, following discussions that ended on April 13, 2010, with the officials of Costa Rica on economic developments and policies. Based on information available at the time of these discussions, the staff report was completed on May 14, 2010. The views expressed in the staff report are those of the staff team and do not necessarily reflect the views of the Executive Board of the IMF.

- $\quad$ A Press Release summarizing the views of the Executive Board as expressed during its May 28, 2010 discussion of the staff report that completed the review.

- $\quad$ A statement by the Executive Director for Costa Rica.

The document listed below has been or will be separately released.

Letter of Intent sent to the IMF by the authorities of Costa Rica*

*Also included in Staff Report

The policy of publication of staff reports and other documents allows for the deletion of market-sensitive information.

\author{
Copies of this report are available to the public from \\ International Monetary Fund • Publication Services \\ $70019^{\text {th }}$ Street, N.W. • Washington, D.C. 20431 \\ Telephone: (202) 623-7430 • Telefax: (202) 623-7201 \\ E-mail: publications@imf.org Internet: http://www.imf.org
}

\section{International Monetary Fund \\ Washington, D.C.}


This page intentionally left blank 


\title{
INTERNATIONAL MONETARY FUND
}

\section{COSTA RICA}

\section{Third and Final Review Under the Stand-By Arrangement}

\author{
Prepared by the Western Hemisphere Department
}

(In consultation with other departments)

Approved by Miguel A. Savastano (WHD) and Dominique Desruelle (SPR)

May 14, 2010

EXECUTIVE SUMMARY
Costa Rica's economic recovery is firming up. The rebound in activity is now broad-based
and projected real GDP growth for 2010 has been revised upward to 3.8 percent (from
2.3 percent previously). End-year inflation is likely to remain close to the upper end of the
central bank's target range of $4-6$ percent. The exchange rate has appreciated in recent months,
as external financial conditions continue to improve.
Performance under the Stand-By Arrangement (SBA) has remained strong. All
quantitative performance criteria for end-December 2009 and end-March 2010 were met. The
structural benchmarks related to the deposit insurance and bank resolution framework were
delayed due to a longer-than-expected consultation process. The authorities have continued to
treat the SBA as precautionary. The staff supports completion of the third and final review.
There are upside risks to the short-term growth outlook. Strong domestic demand,
including from public spending, could bring output growth above 4 percent in 2010 . Given
these prospects, it would seem advisable to start withdrawing fiscal stimulus this year, as was
envisaged in the program.
The medium-term outlook remains favorable, but further policy efforts are needed. It
would be important to adopt a strategy that delivers fiscal consolidation starting in 2011.
Recent gains in lowering inflation should be consolidated including through the adoption of
inflation targeting framework to bolster policy credibility. Approval of legislation to strengthen
supervision and resilience of the financial system should remain a priority.
Global crisis impact. Their authorities' proactive response to the crisis was instrumental to
support domestic demand, reducing the depth of the downturn, and creating a solid basis for
the recovery. The Fund's support helped maintain confidence in the consistency of policies and
the strength of the financial buffers.




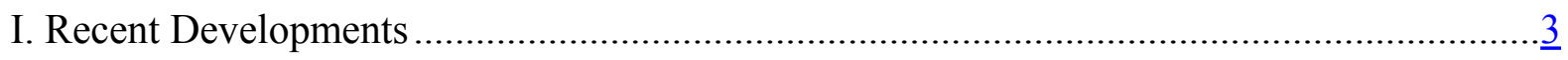

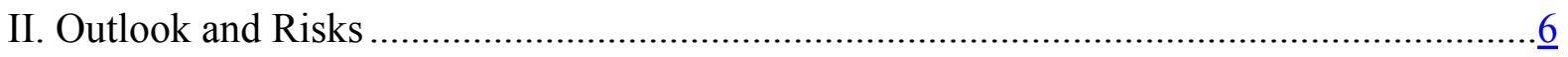

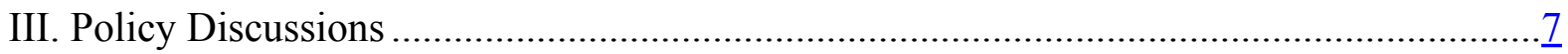

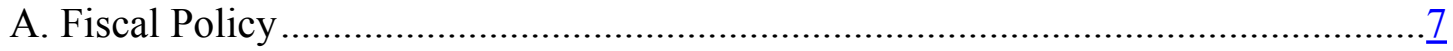

B. Monetary and Exchange Rate Policies............................................................

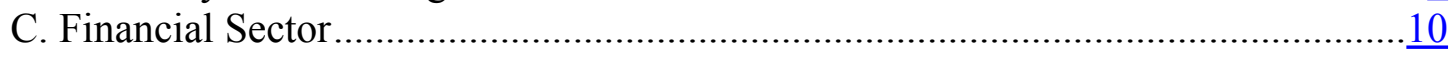

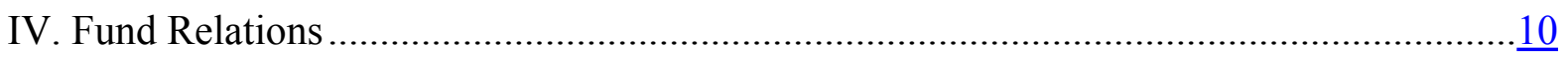

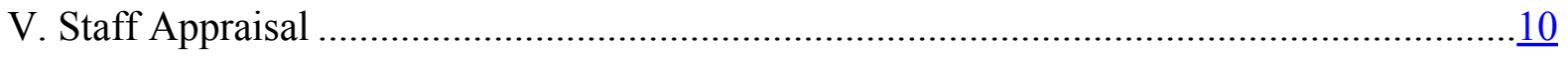

Tables

1. Quantitative Performance Measures …............................................................... 13

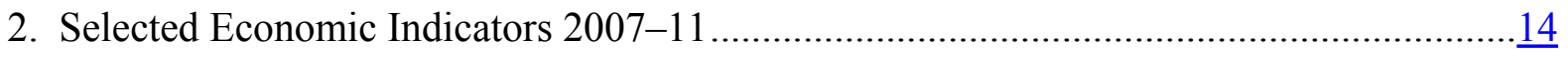

3. Balance of Payments 2007-11 ................................................................................. 15

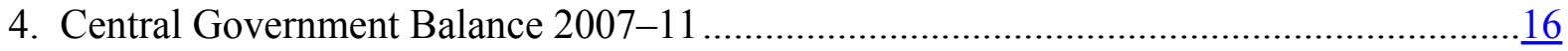

5. Central Government Balance 2007-11 ........................................................................ 17

6. Combined Public Sector Operations 2007-11 …...................................................... 18

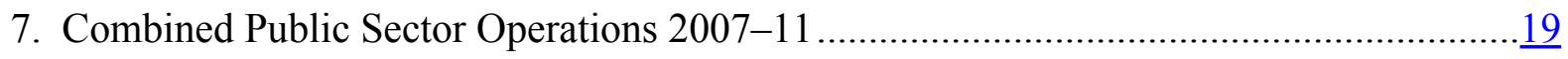

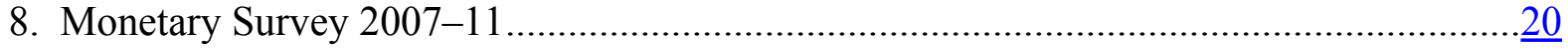

9. External Financing Requirements and Sources 2007-11 ..........................................21

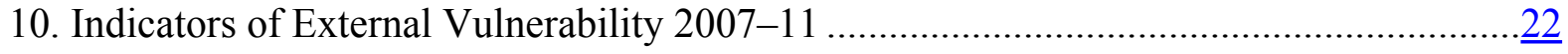

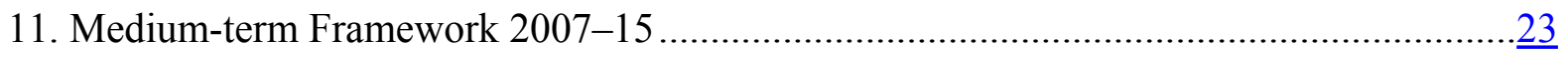

Figures

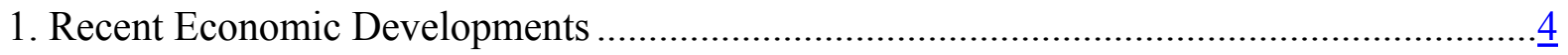

Attachment

Letter of Intent 


\section{RECENT DEVELOPMENTS ${ }^{1}$}

1. A new government took office in May 2010. Ms. Laura Chinchilla, of the ruling National Liberation Party (PLN), won the presidential election in the first round on February 7. The new government intends to give priority to strengthening law enforcement, and boosting the quality of public education. Implementing major structural reforms will require building consensus among political parties, given that the PLN did not obtain a majority in Parliament.

2. The economic recovery is firming up. Real GDP growth rose to 2.9 percent (y/y) in the fourth quarter of 2009, up from negative 0.2 percent in the third quarter (see Figure 1). Several indicators point at further improvement during the first quarter of 2010, including the monthly index of economic activity and the surveys of consumer and business sentiment. Headline inflation rose from 4 percent (y/y) in December 2009 to 5.8 percent in March 2010 owing to increases in administered prices in the first quarter of the year; core inflation, however, remained broadly stable (4 percent as of end-March).
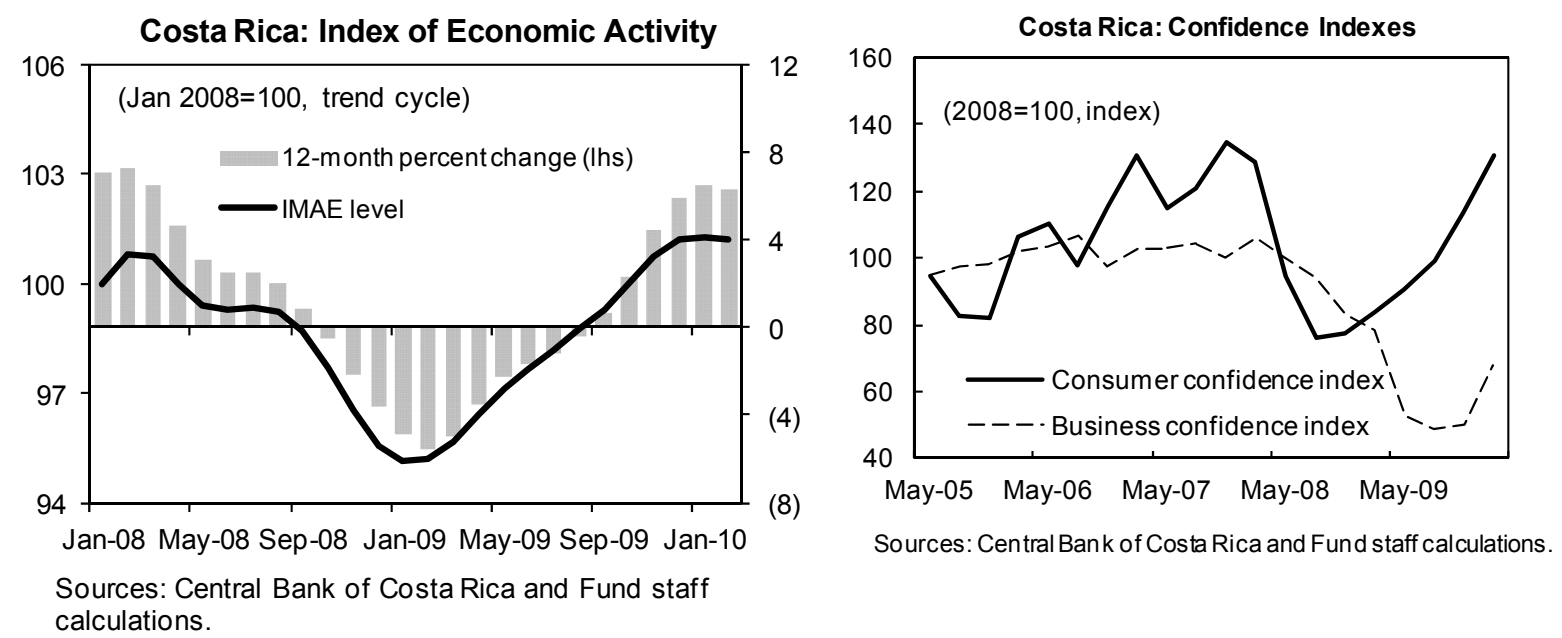

3. The fiscal outturn in $\mathbf{2 0 0 9}$ was better than projected. The deficit of the central government at end-2009 was 3.6 percent of GDP ( 0.5 percentage point of GDP lower than in the program) while the deficit of the combined public sector was 4 percent of GDP ( 0.8 percentage points lower than in the program). The over-performance was explained by

\footnotetext{
${ }^{1}$ Discussions on the third program review were held in San José during April 7-13, 2010. The staff team comprised M. Piñon (Head), R. Luzio, M. Nozaki (all WHD), and O. Melander (SPR), and was joined in some meetings by J. Gramajo (OED), A. Bauer (MCD, outgoing mission chief), and F. Delgado (Regional Resident Representative). The mission met with Finance Minister Phillips, Central Bank Governor Gutiérrez, other senior officials, representatives of the financial sector, and the economic team of the incoming government.
} 
Figure 1. Costa Rica: Recent Economic Developments
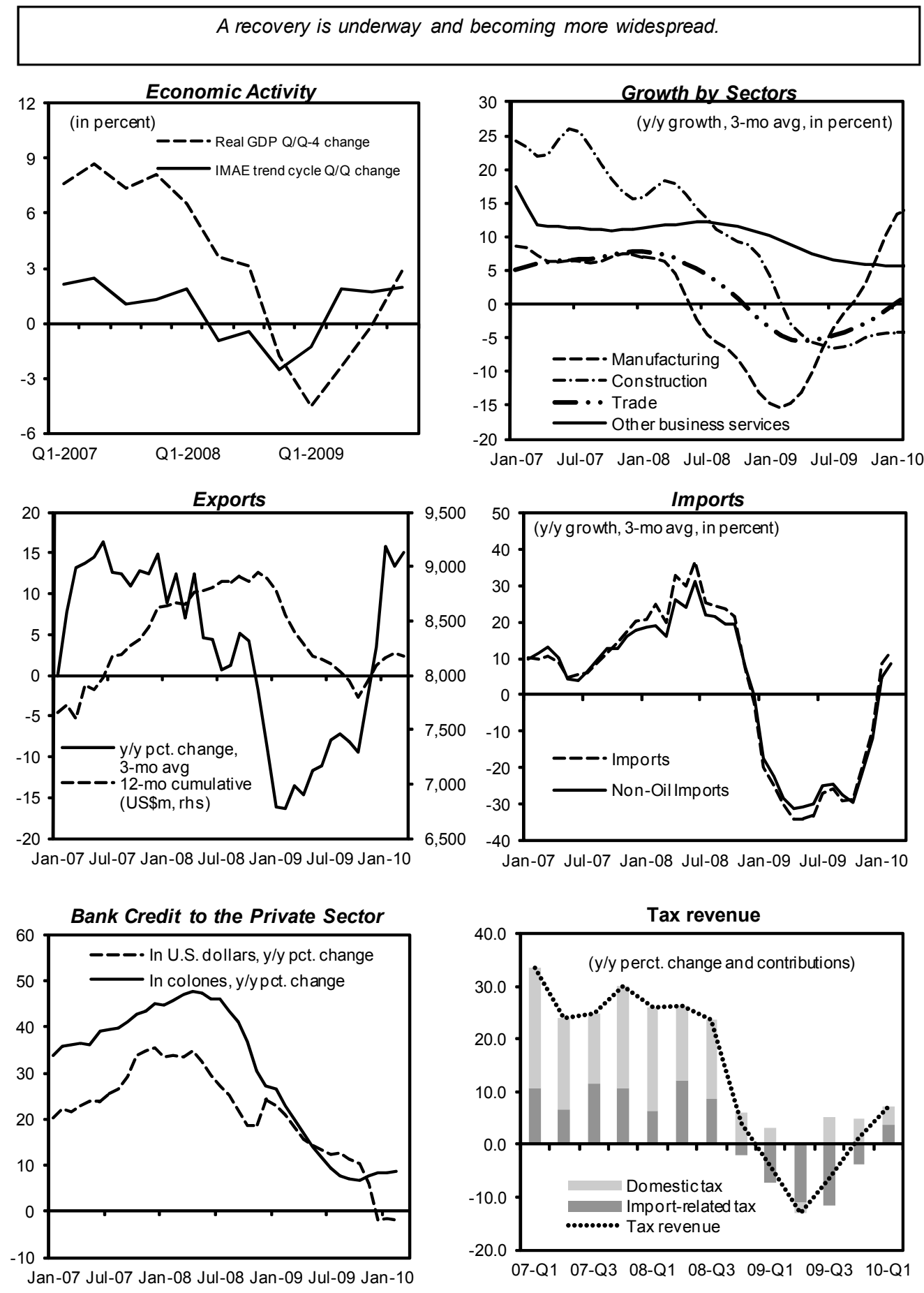

Sources: Country authorities; and Fund staff calculations. 
expenditure restraint (on wages and investment), and by a larger-than-projected surplus of the social security fund (due to a one-off transfer of funds from a closed-down entity). Tax revenues were in line with projections, owing to strong import-related taxes (import duties and sales and consumption taxes collected at customs).

4. The external current account deficit in $\mathbf{2 0 0 9}$ was smaller than envisaged and the overall balance of payments recorded a minor surplus. The fall in imports during the year (26 percent) was larger than projected and also bigger than the decline in exports and tourism-related receipts. The surplus in the capital account also was lower than envisaged, though FDI flows held up relatively well especially in the last months of the year. Overall, net international reserves (excluding the SDR allocation) increased by about $\$ 62$ million in 2009.

5. The colón has continued to appreciate. The currency has strengthened by 10 percent since end-2009 and, as of end-April, stood 2 percent above the floor (23 percent below the ceiling) of the currency band. Strong pickup of balance of payments net flows (both from the current and capital accounts, particularly non-FDI private flows) and a modest decline in the foreign exchange position of banks in the first quarter of the year have driven the appreciation pressures. Lower global risks and a high interest rate differential on shortterm government paper (at about 7-8 percent) have also contributed.
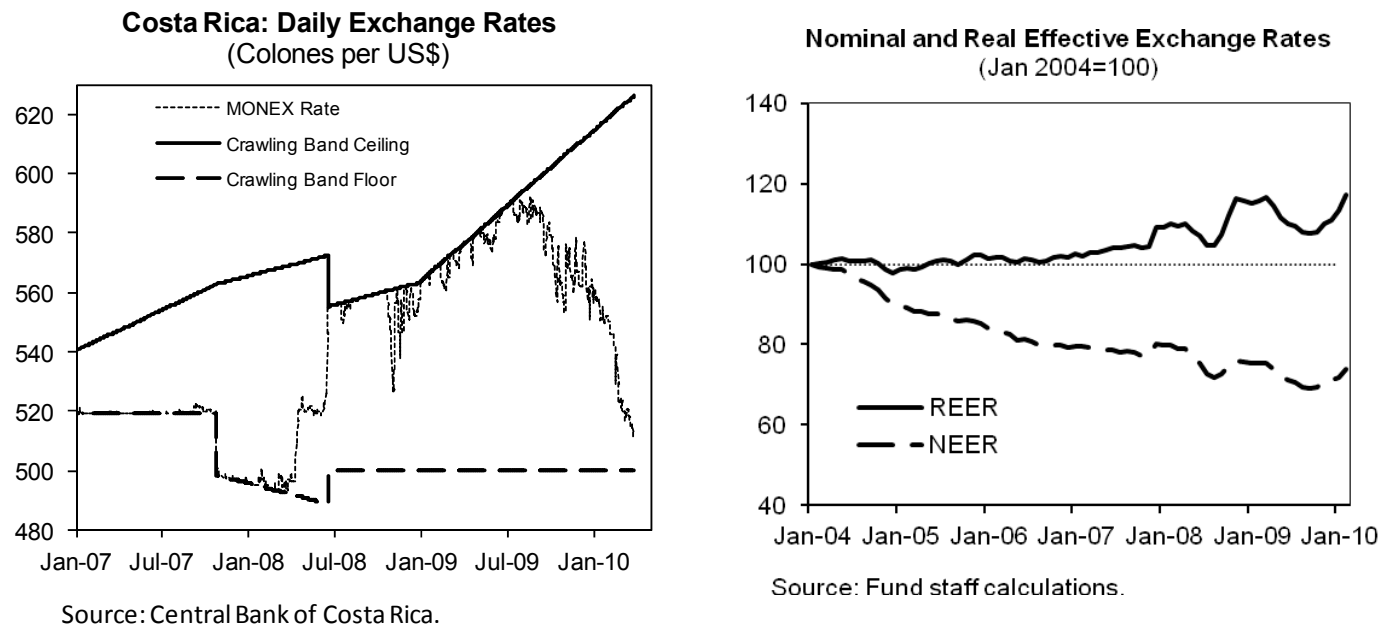

6. The banking system remains sound. The modest deterioration in prudential indicators observed in 2009 has started to reverse. The risk-adjusted capital adequacy ratio of the banking sector rose to 16.3 percent in February 2010, up 0.4 percentage points from end2009. Similarly, nonperforming loans have stabilized at about 2 percent, and continue to be appropriately provisioned. Bank credit growth remains in positive territory and is showing signs of stabilizing. In February 2010, the authorities intervened the fourth largest cooperative COOPEMEX (less than 1 percent of total banking system assets) because of 
persistent capital shortfalls. The intervention generated no market reaction and there were no spillovers to the rest of the system.

7. Performance under the program remained strong. All quantitative performance criteria for end-December 2009 and end-March 2010 were met (Table 1). Base money growth was broadly in line with program projections, and the targets for net international reserves and net domestic assets of the central bank were met with wide margins. The targets on the deficit of the central government were also met. Draft laws to create limited deposit insurance and strengthen the bank resolution framework (end-December 2009 structural benchmarks) were submitted to Parliament in early May due to delays in reflecting the feedback received from various stakeholders.

\section{OUTLOOK AND RISKS}

\section{The economic outlook has improved since the second program review in}

December 2009. A faster than expected recovery has prompted an upward revision to the output growth rates projected for 2010 and 2011 (Text Table 1). At the same time, end-2010 inflation has been revised upward to 6 percent due to recent increases in regulated prices, a higher projected rise in food and fuel prices, and stronger domestic demand. The external current account deficit is still projected to exceed 4 percent of GDP by end-2010, on account of a strong rebound of imports, but prospects for FDI inflows and other capital flows have improved and the overall balance of payments is now projected to post a surplus of US\$200 million (US\$100 million previously).

\begin{tabular}{|c|c|c|c|c|}
\hline & \multirow{3}{*}{$\frac{2009}{\text { Prel. }}$} & \multicolumn{3}{|c|}{ Projection } \\
\hline & & \multicolumn{2}{|c|}{2010} & \multirow{2}{*}{$\begin{array}{c}2011 \\
\text { Revised }\end{array}$} \\
\hline & & Prog. 1/ & Revised & \\
\hline Real GDP & -1.1 & 2.3 & 3.8 & 4.2 \\
\hline Inflation (end of period) & 4.0 & 5.0 & 6.0 & 5.0 \\
\hline Combined public sector balance & -4.0 & -4.7 & -4.5 & -3.4 \\
\hline Central government balance & -3.6 & -4.1 & -4.0 & -3.0 \\
\hline External current account & -2.2 & -4.5 & -4.2 & -4.5 \\
\hline NIR(US\$ million) 2/ & 4,066 & 4,104 & 4,266 & 4,466 \\
\hline
\end{tabular}

9. Risks to the outlook are tilted to the upside. The revised growth projections assume that the pace of economic activity moderates in the second half of 2010 . However, rising incomes and improving confidence, combined with the continued support of government spending, could result in stronger domestic demand growth. Also, improving external and domestic financing conditions could provide an additional boost to private consumption and investment. In that case, there could be upward pressures on inflation and the external current account deficit. Remaining downside risks are mainly related to the strength of the global 
recovery and possible disruptions in international capital markets; on the whole, however, those risks appear lower than a few months ago.

\section{Policy Discussions}

10. Policy discussions focused on the near-term macroeconomic outlook and challenges. The discussions were held with the outgoing economic team, but the mission also met key members of the incoming administration. There was agreement that the main challenges of macroeconomic policy in the months ahead entail rebalancing the policy mix, starting fiscal consolidation, and making further progress on the transition to inflation targeting and greater exchange rate flexibility. These discussions were informed by the policy response during the crisis: (i) a prudent fiscal stance in the years prior to the crisis made possible a countercyclical fiscal response, which highlights the value of fiscal buffers; and (ii) monetary policy was initially constrained by high inflation, which points to the merit of continuing the transition toward a more effective monetary and exchange rate regime.

\section{A. Fiscal Policy}

\section{The (small) withdrawal of fiscal stimulus that was envisaged for 2010 is not} likely to materialize. As noted, the deficit of the central government for 2010 is now projected to be somewhat smaller (in nominal terms and in percent of GDP) than what was envisaged during the second review. However, because the fiscal outturn in 2009 was better than expected (i.e. expenditures were lower), the fiscal impulse during 2010 will be broadly neutral, instead of (mildly) contractionary.

\section{Staff recommended keeping government spending in 2010 in check and adhering} to the strategy agreed in the second review. Staff argued that a modest withdrawal of stimulus would still be useful to rebalance the policy mix and lay the conditions for fiscal consolidation. The authorities agreed that a somewhat tighter fiscal policy stance would be desirable, especially if the exchange rate appreciation pressures continue. However, they noted that it would be difficult to cut spending below the level currently projected or adopt new revenue measures during the second half of the year, given the political transition.

\section{Staff suggested to develop a strategy consistent with fiscal consolidation starting}

in 2011. It presented an illustrative scenario showing that without further measures, the central government deficit would stabilize at around 4 percent of GDP and the public debt-to-GDP ratio would rise to 44 percent by 2015 even if government spending slows down significantly in 2012 (see text table). A second scenario showed that measures equivalent to 2 percentage points of GDP (all assumed on the revenue side for illustrative purposes) would be necessary to lower the public debt ratio to pre-crisis levels over the medium term, as discussed during the 2009 Article IV consultation. The incoming authorities noted that they were strongly committed to prudent fiscal management, and indicated that they planned to formulate a medium-term fiscal strategy in the second half of 2010. 
Text Table 2: Costa Rica: Alternative fiscal scenarios, 2007-2015

\begin{tabular}{|c|c|c|c|c|c|c|c|c|c|c|c|c|c|c|c|}
\hline & \multirow[b]{2}{*}{2007} & \multirow[b]{2}{*}{2008} & \multirow[b]{2}{*}{2009} & \multicolumn{6}{|c|}{ Passive scenario } & \multicolumn{6}{|c|}{ Active scenario } \\
\hline & & & & 2010 & 2011 & 2012 & 2013 & 2014 & 2015 & 2010 & 2011 & 2012 & 2013 & 2014 & 2015 \\
\hline & \multicolumn{15}{|c|}{ (In percent of GDP) } \\
\hline \multicolumn{16}{|l|}{ Central government (CG) } \\
\hline Revenue & 15.5 & 15.9 & 14.1 & 14.7 & 14.9 & 15.0 & 15.0 & 15.1 & 15.2 & 14.7 & 15.9 & 17.0 & 17.0 & 17.1 & 17.2 \\
\hline Expenditure & 15.2 & 16.1 & 17.7 & 18.7 & 18.9 & 18.9 & 19.0 & 19.1 & 19.2 & 18.7 & 18.9 & 18.8 & 18.8 & 18.7 & 18.6 \\
\hline Primary balance & 3.7 & 2.4 & -1.3 & -1.3 & -1.4 & -1.3 & -1.3 & -1.2 & -1.1 & -1.3 & -0.4 & 0.7 & 0.7 & 0.8 & 0.9 \\
\hline Overall Balance & 0.3 & -0.3 & -3.6 & -4.0 & -4.0 & -4.0 & -4.0 & -4.0 & -4.0 & -4.0 & -3.0 & -1.9 & -1.7 & -1.5 & -1.4 \\
\hline \multicolumn{16}{|c|}{ Combined public sector (CPS) } \\
\hline Overall balance & 1.2 & 0.1 & -4.0 & -4.5 & -4.4 & -4.3 & -4.3 & -4.3 & -4.3 & -4.5 & -3.4 & -2.2 & -2.0 & -1.8 & -1.6 \\
\hline CPS debt & 43.2 & 35.7 & 37.9 & 37.9 & 39.2 & 40.4 & 41.5 & 42.7 & 44.0 & 37.9 & 38.2 & 37.4 & 36.4 & 35.7 & 34.9 \\
\hline \multicolumn{16}{|l|}{ Memorandum items: } \\
\hline Real GDP growth rate (\%) & 7.9 & 2.8 & -1.1 & 3.8 & 4.2 & 4.4 & 4.5 & 4.4 & 4.4 & 3.8 & 4.2 & 4.4 & 4.5 & 4.4 & 4.4 \\
\hline \multicolumn{16}{|l|}{ Real growth rate $(\%)$} \\
\hline CG primary spending & 11.1 & 13.8 & 15.9 & 8.1 & 6.3 & 4.5 & 4.5 & 4.5 & 4.5 & 8.1 & 6.3 & 4.5 & 4.5 & 4.5 & 4.5 \\
\hline CPS primary spending & 9.9 & 14.6 & 13.4 & 8.3 & 5.6 & 4.3 & 4.5 & 4.4 & 4.4 & 8.3 & 5.6 & 4.3 & 4.5 & 4.4 & 4.4 \\
\hline
\end{tabular}




\section{B. Monetary and Exchange Rate Policies}

\section{The authorities agreed that the central bank should focus on consolidating} recent gains on price stability. The authorities noted that the recent uptick of headline inflation was due to larger-than-expected increases in some administered prices and that there were no signs of underlying price pressures. They also believed that the recent exchange rate appreciation would help keep inflation low. Staff noted that the improved growth outlook was likely to reignite inflation pressures and advised the central bank to maintain its cautious stance and stand ready to tighten preemptively to avoid locking in high inflation.

15. The authorities recognized that the exchange rate band currently in place did not leave much room for additional appreciation, but did not think that conditions were ripe for a change in the exchange rate system. In particular, they were concerned that the elimination of the band or a downward shift of the floor at the present juncture would trigger an abrupt appreciation as occurred in 2008. Staff stressed that if the colón were to reach the bottom of the band, intervention would have to be sterilized to avoid creating an excessive monetary expansion. Staff agreed with the authorities that, if the appreciation were the result of an increase in demand for domestic money, there would be less need to sterilize the monetary expansion, but noted that there was no clear evidence of significant dedollarization taking place.

\section{There was agreement that the exchange rate continues to be consistent with}

fundamentals. Although updated estimates of misalignment obtained from the standard methodologies suggest an overvaluation (compared to a near balance reported during the last Article IV consultation), the estimates remain within the margin of error. Nonetheless, the authorities noted that exporters were becoming concerned about the impact of the appreciation on competitiveness.

\section{Staff encouraged the authorities to accelerate the transition to greater exchange} rate flexibility and inflation targeting. To this end, staff recommended that the central bank start to gradually absorb banks' excess liquidity in order to increase the effectiveness of the policy rate as a monetary instrument. The authorities argued that such a change in operating procedure would have to be gradual to allow banks time to adjust to an environment of less liquidity. The authorities also reiterated that a mechanism to contain excessive short-term exchange rate volatility would need to be put in place as they move further toward exchange rate flexibility. They agreed with staff that such measures would have to be rules-based and transparent to avoid the perception that the central bank is targeting a particular exchange rate level. 


\section{Financial Sector}

18. The authorities concurred that, while conditions were improving, continued vigilance of the financial sector was warranted. They considered that Costa Rica's financial system had weathered the downturn relatively well and that prudential indicators would improve as activity gains momentum. In addition, they noted that the banking sector was well-capitalized and maintained comfortable liquidity positions. Staff noted that the prompt intervention of COOPEMEX reflected the authorities' pro-active approach to take corrective actions, but the event also underscored some limitations in the resolution framework for financial institutions.

\section{Implementing pending reforms to strengthen the safety net of the financial} sector remained a priority. The authorities were of the view that adopting the deposit insurance and resolution framework, contained in the draft laws sent to parliament, would help increase the resilience and confidence on the domestic financial sector. They explained that the proposed legislation excluded commercial public banks, which already benefit from an explicit government guarantee. Staff impressed on the authorities the importance of securing approval of all financial system laws, including those related to consolidated banking supervision and central bank recapitalization.

\section{FUnd RELATIONS}

20. The incoming authorities expressed interest in maintaining a close dialogue with the Fund. They noted that they intend to define the elements of their economic strategy later in the year and would welcome Fund staff's advice, including in the context of the upcoming Article IV consultation. Staff noted the importance of designing a budget for 2011 consistent with the goal of starting fiscal consolidation and bringing down the public debt over the medium term to pre-crisis levels. It also highlighted the importance of reviving the structural reform agenda to raise productivity. The authorities noted that they will give high priority to maintaining sound policies, and will make sure that the government's goal of strengthening law enforcement and boosting investment in education and infrastructure are consistent with that objective.

\section{Staff Appraisal}

\section{Appropriate macroeconomic policies, supported by a precautionary SBA,} mitigated the impact of the crisis and provided a strong foundation for a recovery. Countercyclical policies, particularly on the fiscal side, shielded the Costa Rican economy from the external shock, and protected the most vulnerable groups. At the same time, the authorities' efforts to mobilize external resources, including from the Fund and other IFIs, provided a significant element of insurance which supported policy credibility and helped manage expectations. 
22. The recovery of Costa Rica's economy is firmly underway. The recent acceleration of economic activity is more robust than anticipated and is becoming widespread. Rising consumer and business confidence should help consolidate domestic demand. The balance of payments position has strengthened, and credit growth is poised to pick up in the near term.

23. Performance under the precautionary SBA has remained strong. All quantitative performance for end-December 2009 and end-March 2010 were met. Draft laws to create limited deposit insurance and strengthen the bank resolution framework (end-December 2009 structural benchmarks) were delayed due to a longer-than-expected consultation process.

24. As the recovery becomes stronger and more self-sustained, it will be important that the authorities gear the policy stance toward preserving macroeconomic stability. With domestic demand likely to continue strong in the near term, there is upside risk to growth. Financial conditions are improving and bank credit is expected to rebound as firms' and consumers' appetite for credit picks up. Appreciation pressures highlight the importance of tighter fiscal policy to rebalance the policy mix.

25. It will be desirable to start withdrawing fiscal stimulus in $\mathbf{2 0 1 0}$ and aim for considerable fiscal consolidation starting in 2011. The expansion of the fiscal stance was instrumental in softening the impact of the external crisis in 2009. However, as growth accelerates, a modest withdrawal of fiscal stimulus in 2010, as envisaged under the program, would be advisable to rebalance the policy mix and reduce the burden on monetary policy. In addition, it will be essential to formulate a strategy of fiscal consolidation starting in 2011 to restore the fiscal space used during the crisis and help reverse the recent increase in the public debt-to-GDP ratio.

26. Monetary policy should focus on locking in low inflation. With inflation expectations above the central bank's end-year inflation target range, the recent increase in headline inflation poses challenges. It will be important that the central bank stands ready to tighten the policy stance if inflation pressures persist, especially if fiscal policy is slow to unwind the current stimulus. Monetary policy would become more challenging if the exchange rate were to reach the bottom of the band. In such scenario, foreign exchange intervention should be sterilized to avoid excessive monetary expansion.

27. The transition to inflation targeting and greater exchange rate flexibility should remain a priority. A gradual mopping up of excess bank liquidity would be helpful to improve the monetary transmission process and the effectiveness of the central bank's instruments. As they allow greater exchange rate flexibility, the authorities could consider introducing a transparent, rules-based intervention mechanism to avoid excessive short-term exchange rate volatility. 


\section{The new government should seek prompt approval of important economic}

legislation currently with congress. The failure of a small cooperative bank highlighted the importance of the proposed legislation to create limited deposit insurance and strengthen the bank resolution framework. Approval of the proposed legislation on central bank recapitalization and consolidated financial sector supervision will also be important.

29. Staff recommends the approval of the third review under the SBA. Performance under the program has been strong, and the authorities' policies continue to be adequate to support economic recovery while maintaining internal and external stability. 
Table 1. Costa Rica: Quantitative Performance Measures

(In billion of colones, unless otherwise indicated)

\begin{tabular}{|c|c|c|c|c|c|c|c|c|c|c|}
\hline & \multicolumn{8}{|c|}{2009 Program } & \multirow{2}{*}{\multicolumn{2}{|c|}{$\begin{array}{c}2010 \text { Program } \\
\text { End-March 1/ } \\
\end{array}$}} \\
\hline & \multicolumn{2}{|c|}{ End-March } & \multicolumn{2}{|c|}{ End-June } & \multicolumn{2}{|c|}{ End-September } & \multicolumn{2}{|c|}{ End-December } & & \\
\hline & Prog. 2/ & Actual & Prog. 2/ & Actual & Prog. 3/ & Actual & Prog. 4/ & Actual & Prog. 4/ & Actual \\
\hline \multicolumn{11}{|l|}{ Quantitative Performance Criteria } \\
\hline Floor on cash balance of the Central Government (cumulative) & -210 & -106 & -312 & -206 & -471 & -377 & -639 & -573 & -322 & -261 \\
\hline Ceiling on the debt stock of the Central Government & 4,303 & 4,239 & 4,356 & 4,338 & 4,753 & 4,551 & 4,914 & 4,622 & 5,286 & 4,884 \\
\hline Ceiling on NDA of the Central Bank 5/ & -915 & $-1,301$ & -786 & $-1,244$ & -970 & $-1,170$ & -896 & $-1,133$ & -807 & $-1,240$ \\
\hline Floor on NIR of the Central Bank (million of US $\$$ ) 5 / & 3,500 & 4,167 & 3,350 & 3,936 & 3,555 & 4,059 & 3,705 & 4,066 & 3,405 & 4,155 \\
\hline \multicolumn{11}{|l|}{ Continuous Performance Criteria } \\
\hline Accumulation of external debt arrears & 0 & 0 & 0 & 0 & 0 & 0 & 0 & 0 & 0 & 0 \\
\hline \multicolumn{11}{|l|}{ Indicative targets } \\
\hline Floor on cash balance of the combined public sector (cumulative) & -146 & -43 & -325 & -179 & -524 & -411 & -774 & -655 & -352 & $\ldots$ \\
\hline \multicolumn{11}{|l|}{ Memorandum item } \\
\hline Base money & 1,102 & 1,101 & 1,144 & 1,024 & 1,079 & 1,170 & 1,240 & 1,210 & 1,155 & 1,155 \\
\hline Program exchange rate (ask price, colones per U.S. dollar) & 576 & 558 & 576 & 569 & 576 & 576 & 576 & 576 & 576 & 576 \\
\hline
\end{tabular}

Sources: Central Bank of Costa Rica; Ministry of Finance; and Fund staff projections.

1/ The end-March 2010 quantitative PCs are evaluated at the 2009 program exchange rates (as defined in the TMU for the first review (IMF Country Report No. 09/303)).

2/ IMF Country Report No. 09/134.

3/ IMF Country Report No. 09/303.

4/ IMF Country Report No. 10/2.

5/ The floor on NIR and ceiling on NDA at end-September and end-December 2009 have been adjusted by $\$ 209$ million compared to the levels set at program approval (IMF Country Report No. 09/134). to reflect the special and general SDRs allocations of 132.81 millions SDRs. 
Table 2. Costa Rica: Selected Economic Indicators 2007-11

\begin{tabular}{|c|c|c|c|c|c|c|c|c|}
\hline \multirow{3}{*}{$\begin{array}{l}\text { Per capita GDP (2008, U.S. dollars) } \\
\text { Population (July } 2008, \text { millions) } \\
\text { Life expectancy (2005, years) }\end{array}$} & 6,583 & \multicolumn{5}{|c|}{ Unemployment (2009, percent of labor force) } & \multicolumn{2}{|l|}{7.8} \\
\hline & 4.5 & \multicolumn{5}{|c|}{ Poverty (2009, percent of hous eholds) } & 18.5 & \\
\hline & 79.1 & \multicolumn{5}{|c|}{ Extreme poverty (2009, percent of households) } & \multicolumn{2}{|l|}{4.2} \\
\hline & & \multirow[t]{2}{*}{2007} & 2008 & \multicolumn{2}{|c|}{2009} & \multicolumn{2}{|c|}{2010} & 2011 \\
\hline & & & & Progr. 1/ & Prel. & Prog. 1 & Proj. & Proj. \\
\hline
\end{tabular}

National Income and Prices

GDP at constant prices

Implicit deflator

Consumer prices (end of period)

(Annual percentage change, unless otherwise indicated)

$\begin{array}{rrrrrrr}7.9 & 2.8 & -1.5 & -1.1 & 2.3 & 3.8 & 4.2 \\ 9.4 & 12.3 & 8.9 & 8.1 & 6.0 & 6.5 & 5.7 \\ 10.8 & 13.9 & 5.0 & 4.0 & 5.0 & 6.0 & 5.0 \\ & & & & & & \\ 9.2 & -4.2 & -8.2 & -6.3 & 3.1 & 4.5 & 4.8 \\ 3.7 & 7.7 & -17.8 & -17.3 & 7.5 & 10.4 & 8.1 \\ -4.0 & -3.5 & 4.9 & 5.8 & -1.8 & -1.2 & -1.5 \\ 2.8 & 5.3 & \ldots & 1.7 & \ldots & \ldots & \ldots \\ & & & & & & \\ 33.0 & 11.9 & 7.7 & 5.1 & 9.7 & 7.2 & 10.4 \\ 16.3 & 17.3 & 16.2 & 8.6 & 13.0 & 17.7 & 11.9 \\ 38.3 & 31.8 & 5.6 & 4.5 & 13.1 & 7.0 & 14.0 \\ 16.3 & 20.7 & \ldots & 20.2 & \ldots & \ldots & \ldots\end{array}$

\section{External Sector}

Exports of goods (volume, fob)

Imports of goods (volume, cif)

Terms of trade (deterioration -)

Real Effective Exchange Rate (eop; depreciation -)

Money and Credit

Base money

Broad money

Bank credit to private sector

Lending interest rate (end of period)

Public Finances

Combined public sector primary balance 2/

Combined public sector overall balance $2 /$

Central government balance

Social security balance

Central bank balance

Other public enterprises and entities balance

Combined public sector debt (gross) $2 /$

Of which: External public debt $3 /$

$\begin{array}{rr}4.1 & 2.2 \\ 1.2 & 0.1 \\ 0.3 & -0.3 \\ 1.2 & 0.6 \\ -0.7 & -0.2 \\ 0.4 & 0.0 \\ 43.2 & 35.7 \\ 7.8 & 5.5\end{array}$

(In percent of GDP)

\section{Savings and Investment}

Gross domestic investment

Gross national savings

External Sector

Trade balance

Current account balance

Foreign direct investment

$\begin{array}{rr}24.7 & 27.5 \\ 18.4 & 18.3 \\ & \\ -11.3 & -16.8 \\ -6.3 & -9.2 \\ 6.2 & 6.8\end{array}$

$\begin{array}{rr}-2.5 & -1.8 \\ -4.8 & -4.0 \\ -4.1 & -3.6 \\ 0.2 & 0.5 \\ -0.8 & -0.8 \\ -0.1 & -0.1 \\ 39.9 & 37.9 \\ 5.5 & 4.9\end{array}$

$\begin{array}{rrr}-2.3 & -2.1 & -1.3 \\ -4.7 & -4.5 & -3.4 \\ -4.1 & -4.0 & -3.0 \\ 0.1 & 0.0 & 0.1 \\ -0.6 & -0.6 & -0.5 \\ 0.0 & 0.1 & 0.0 \\ 41.6 & 37.9 & 38.2 \\ 6.7 & 5.3 & 4.8\end{array}$

(In millions of U.S. dollars, unless otherwise indicated)

Change in net international reserves (increase -)

Net international reserves 4/

-in months of nonmaquila imports of G\&S

Gross Domestic Product

$\begin{array}{ll}14.8 & 13.8 \\ 11.8 & 11.6-(-2 \\ \end{array}$

$\begin{array}{rrrrr}-8.8 & -6.9 & -11.3 & -8.7 & -9.8 \\ -3.0 & -2.2 & -4.5 & -4.2 & -4.5 \\ 4.1 & 4.5 & 4.3 & 4.1 & 4.5\end{array}$

\footnotetext{
Sources: Central Bank of Costa Rica; Ministry of Finance; and Fund staff projections.

1/ Staff report for the second review of the Stand-By Arrangement (IMF Country Report No. 10/2).

$2 /$ Combined Public sector $=$ Central government + Central bank + Other public enterprises and entities, excluding Instituto de Electricidad (ICE).

3/ The revision from IMF Country Report No. 09/303 reflects an application of the residency criterion to measure external debt. 4/ Includes valuation adjustments of US\$160 million in 2007 for reclassification of capital contribution to FLAR and US $\$ 209$ million in 2009 for SDR allocation.
} 
Table 3. Costa Rica: Balance of Payments 2007-11

(In millions of U.S. dollars, unless otherwise indicated)

\begin{tabular}{|c|c|c|c|c|c|c|c|}
\hline & 2007 & 2008 & 20 & & 20 & & 2011 \\
\hline & & & Prog. 1/ & Prel. & Prog. 1/ & Proj. & Proj. \\
\hline Current Account & $-1,646$ & $-2,754$ & -890 & -634 & $-1,384$ & $-1,468$ & $-1,751$ \\
\hline Trade balance & $-2,985$ & $-5,014$ & $-2,589$ & $-2,024$ & $-3,437$ & $-3,069$ & $-3,807$ \\
\hline Trade balance goods for processing & 2,214 & 1,859 & 2,463 & 2,252 & 2,199 & 2,362 & 2,282 \\
\hline Export of goods (f.o.b.) & 9,299 & 9,554 & 8,694 & 8,847 & 9,120 & 9,413 & 9,982 \\
\hline General merchandise and others & 3,802 & 4,327 & 3,768 & 3,926 & 4,064 & 4,279 & 4,550 \\
\hline Goods for processing & 5,498 & 5,227 & 4,925 & 4,921 & 5,056 & 5,134 & 5,432 \\
\hline Import of goods (f.o.b.) & 12,285 & 14,569 & 11,283 & 10,871 & 12,557 & 12,482 & 13,789 \\
\hline General merchandise and others & 9,001 & 11,201 & 8,820 & 8,202 & 9,700 & 9,710 & 10,639 \\
\hline Oil products & 1,444 & 2,089 & 1,224 & 1,238 & 1,621 & 1,782 & 1,991 \\
\hline Others & 7,557 & 9,112 & 7,596 & 6,964 & 8,079 & 7,928 & 8,648 \\
\hline Goods for processing & 3,284 & 3,368 & 2,463 & 2,669 & 2,857 & 2,772 & 3,151 \\
\hline Services & 1,734 & 2,253 & 2,246 & 2,158 & 2,340 & 2,262 & 2,471 \\
\hline Of which: Travel & 1,393 & 1,692 & 1,492 & 1,422 & 1,558 & 1,501 & 1,650 \\
\hline Income & -865 & -434 & -877 & $-1,097$ & -636 & $-1,031$ & -799 \\
\hline Of which: Interest on external public debt & -177 & -180 & -180 & -182 & -191 & -204 & -138 \\
\hline Of which: FDI income, net & -998 & -486 & -812 & -976 & -605 & -941 & -811 \\
\hline Current transfers & 470 & 442 & 330 & 329 & 350 & 370 & 385 \\
\hline Financial and Capital Account & 2,315 & 2,416 & 890 & 523 & 1,484 & 1,668 & 1,951 \\
\hline Direct investment & 1,634 & 2,015 & 1,201 & 1,316 & 1,295 & 1,430 & 1,734 \\
\hline Capital flows & 660 & 393 & -311 & -826 & 189 & 238 & 217 \\
\hline Public sector & 0 & 11 & 89 & 302 & 454 & 316 & -91 \\
\hline Disbursements & 236 & 737 & 547 & 596 & 655 & 769 & 682 \\
\hline Amortization (inc. changes in PE deposits) & -237 & -726 & -458 & -295 & -200 & -453 & -773 \\
\hline Private net capital & 660 & 382 & -401 & $-1,128$ & -265 & -78 & 308 \\
\hline Of which: Commercial banks & 830 & 159 & -873 & -825 & 0 & -144 & 112 \\
\hline Of which: Private nonfinancial sector & -170 & 223 & 473 & -303 & -265 & 66 & 195 \\
\hline Errors and Omissions & 171 & 23 & 0 & 174 & 0 & 0 & 0 \\
\hline Change in Net Reserves (increase -) & -839 & 315 & 0 & -62 & -100 & -200 & -200 \\
\hline & & & (Annual & sercentas & change) & & \\
\hline Export of Goods (f.o.b.) & & & & & & & \\
\hline Value & 14.8 & 2.7 & -9.1 & -7.4 & 4.9 & 6.4 & 6.0 \\
\hline Volume & 9.2 & -4.2 & -8.2 & -6.3 & 3.1 & 4.5 & 4.8 \\
\hline Import of Goods (c.i.f.) & & & & & & & \\
\hline Value & 12.7 & 18.2 & -22.4 & -25.5 & 12.5 & 14.8 & 10.6 \\
\hline Volume & 3.7 & 7.7 & -17.8 & -17.3 & 7.5 & 10.4 & 8.1 \\
\hline Of which: oil & & & & & & & \\
\hline Value & 15.6 & 44.7 & -41.4 & -40.7 & 32.4 & 43.9 & 11.8 \\
\hline Volume & 4.6 & 2.6 & -4.9 & -3.7 & 5.6 & 8.1 & 6.0 \\
\hline & & & $(\ln \mathrm{F}$ & ercent of & DP) & & \\
\hline Current account & -6.3 & -9.2 & -3.0 & -2.2 & -4.5 & -4.2 & -4.5 \\
\hline Non-oil current account & -0.8 & -2.2 & 1.1 & 2.1 & 0.8 & 0.9 & 0.6 \\
\hline Export of goods (f.o.b.) & 35.3 & 32.0 & 29.7 & 30.2 & 30.0 & 26.7 & 25.8 \\
\hline Import of goods (f.o.b.) & 46.7 & 48.8 & 38.5 & 37.1 & 41.3 & 35.4 & 35.7 \\
\hline Non-oil goods imports (f.o.b.) & 41.2 & 41.8 & 34.3 & 32.9 & 35.9 & 30.3 & 30.5 \\
\hline Income & -3.3 & -1.5 & -3.0 & -3.7 & -2.1 & -2.9 & -2.1 \\
\hline Direct investment & 6.2 & 6.8 & 4.1 & 4.5 & 4.3 & 4.1 & 4.5 \\
\hline Memorandum Items: & & & & & & & \\
\hline Net international reserves (US $\$$ million) $2 /$ & 4,114 & 3,799 & 4,004 & 4,066 & 4,104 & 4,266 & 4,466 \\
\hline -in months of non-maquila imports & 3.8 & 4.6 & 4.2 & 4.2 & 4.0 & 4.1 & 4.0 \\
\hline -in percent short-term debt $3 /$ & 97.0 & 90.0 & 104.9 & 128.5 & 103.2 & 117.5 & 122.8 \\
\hline External debt $4 /$ & 31.7 & 29.7 & 30.4 & 27.4 & 29.9 & 23.3 & 21.8 \\
\hline
\end{tabular}

Sources: Central Bank of Costa Rica; and Fund staff estimates.

1/ IMF Country Report No. 10/2.

$2 /$ Includes valuation adjustments of US $\$ 160$ million in 2007 for reclassification of capital contribution to FLAR and US $\$ 209$ million in 2009 for new SDR allocation.

$3 /$ Public and private sector external debt on remaining maturity. Includes trade credits.

4/ Includes public and private sector debt. 
Table 4. Costa Rica: Central Government Balance 2007-11

(In percent of GDP)

\begin{tabular}{|c|c|c|c|c|c|c|c|}
\hline & \multirow[t]{2}{*}{2007} & \multirow[t]{2}{*}{2008} & \multicolumn{2}{|c|}{2009} & \multicolumn{2}{|c|}{2010} & \multirow{2}{*}{$\frac{2011}{\text { Proj. }}$} \\
\hline & & & Prog. 1/ & Prel. & Prog. 1/ & Proj. & \\
\hline Revenue & 15.5 & 15.9 & 14.2 & 14.1 & 15.0 & 14.7 & 15.9 \\
\hline Tax revenue & 15.2 & 15.6 & 13.9 & 13.8 & 14.7 & 14.4 & 15.6 \\
\hline Direct taxes & 4.6 & 5.1 & 4.7 & 4.9 & 5.1 & 5.1 & 5.9 \\
\hline Sales tax & 5.9 & 6.0 & 5.0 & 4.9 & 5.3 & 5.1 & 5.6 \\
\hline Excise, customs, and others & 4.8 & 4.6 & 4.3 & 4.0 & 4.3 & 4.2 & 4.1 \\
\hline Nontax revenue & 0.3 & 0.2 & 0.3 & 0.3 & 0.3 & 0.3 & 0.3 \\
\hline Expenditure & 15.2 & 16.1 & 18.2 & 17.7 & 19.1 & 18.7 & 18.9 \\
\hline Current noninterest & 10.5 & 11.3 & 13.8 & 13.5 & 14.3 & 14.1 & 14.3 \\
\hline Wages and salaries & 4.4 & 4.6 & 5.8 & 5.6 & 6.0 & 6.0 & 6.3 \\
\hline Pensions and social security & 2.4 & 2.4 & 2.7 & 2.6 & 2.7 & 2.7 & 2.6 \\
\hline Transfers and other & 3.7 & 4.4 & 5.4 & 5.3 & 5.6 & 5.4 & 5.4 \\
\hline Interest & 3.3 & 2.6 & 2.4 & 2.3 & 2.9 & 2.7 & 2.6 \\
\hline o/w adjustment for TUDES $2 /$ & 0.3 & 0.5 & 0.2 & 0.2 & 0.3 & 0.3 & 0.2 \\
\hline Capital & 1.3 & 1.8 & 2.0 & 1.8 & 2.0 & 1.9 & 2.0 \\
\hline Recapitalization of commercial banks & 0.0 & 0.4 & 0.0 & 0.0 & 0.0 & 0.0 & 0.0 \\
\hline Primary Balance & 3.7 & 2.4 & -1.6 & -1.3 & -1.2 & -1.3 & -0.4 \\
\hline Structural primary balance 3/ & 2.7 & 2.0 & -1.5 & -1.2 & -0.8 & -1.2 & -0.4 \\
\hline Overall Balance & 0.3 & -0.3 & -4.1 & -3.6 & -4.1 & -4.0 & -3.0 \\
\hline Structural overall balance $3 /$ & -0.6 & -0.7 & -3.9 & -3.6 & -3.7 & -3.9 & -3.0 \\
\hline Total Financing & -0.3 & 0.3 & 4.1 & 3.6 & 4.1 & 4.0 & 3.0 \\
\hline External (net) & 0.3 & -1.2 & 0.0 & -0.4 & 1.5 & 1.3 & -0.1 \\
\hline Internal (net) & -0.6 & 1.5 & 4.0 & 4.0 & 2.7 & 2.7 & 3.1 \\
\hline \multicolumn{8}{|l|}{ Memorandum Items: } \\
\hline Central government debt & 27.6 & 24.8 & 28.9 & 27.3 & 31.0 & 28.0 & 28.7 \\
\hline External & 5.7 & 4.3 & 4.3 & 3.6 & 5.6 & 4.3 & 3.9 \\
\hline Domestic & 21.9 & 20.5 & 24.6 & 23.7 & 25.4 & 23.7 & 24.8 \\
\hline
\end{tabular}

Sources: Ministry of Finance; and Fund staff estimates.

1/ IMF Country Report No. 10/2.

2/ TUDES are inflation indexed bonds of the central government. The inflation adjustment of principal is not reflected as interest expenditure in the fiscal accounts of the Costa Rican authorities, but is added here to the Fund presentation of the fiscal deficit and public sector debt.

3 / For 2008, excludes one time expense for recapitalization of commercial banks. 
Table 5. Costa Rica: Central Government Balance 2007-11

(In billions of colones)

\begin{tabular}{|c|c|c|c|c|c|c|c|}
\hline & \multirow[t]{2}{*}{2007} & \multirow[t]{2}{*}{2008} & \multicolumn{2}{|c|}{2009} & \multicolumn{2}{|c|}{2010} & \multirow{2}{*}{2011} \\
\hline & & & Prog. 1/ & Prel. & Prog. 1/ & Proj. & \\
\hline Revenue & 2,105 & 2,490 & 2,376 & 2,363 & 2,724 & 2,726 & 3,243 \\
\hline Tax revenue & 2,067 & 2,453 & 2,333 & 2,321 & 2,673 & 2,677 & 3,190 \\
\hline Direct taxes & 622 & 801 & 786 & 820 & 936 & 948 & 1,206 \\
\hline Sales tax & 798 & 937 & 835 & 831 & 960 & 950 & 1,149 \\
\hline Excise, customs, and others & 647 & 715 & 712 & 670 & 778 & 778 & 834 \\
\hline Nontax Revenue & 38 & 37 & 44 & 42 & 51 & 49 & 54 \\
\hline Expenditure & 2,062 & 2,536 & 3,057 & 2,970 & 3,477 & 3,466 & 3,863 \\
\hline Current noninterest & 1,427 & 1,776 & 2,320 & 2,271 & 2,590 & 2,622 & 2,932 \\
\hline Wages and salaries & 601 & 721 & 968 & 936 & 1,090 & 1,118 & 1,280 \\
\hline Pensions and social security & 324 & 372 & 448 & 445 & 488 & 493 & 538 \\
\hline Transfers and other & 503 & 683 & 903 & 890 & 1,012 & 1,011 & 1,114 \\
\hline Interest & 454 & 415 & 408 & 393 & 527 & 499 & 532 \\
\hline o/w adjustment for TUDES 2/ & 35 & 75 & 41 & 33 & 60 & 52 & 51 \\
\hline Capital & 180 & 279 & 329 & 306 & 360 & 344 & 400 \\
\hline Recapitalization of commercial banks & 0 & 65 & 0 & 0 & 0 & 0 & 0 \\
\hline Primary balance & 497 & 370 & -272 & -213 & -226 & -240 & -88 \\
\hline Structural primary balance 3/ & 367 & 311 & -243 & -205 & -144 & -226 & -73 \\
\hline Overall Balance & 43 & -46 & -680 & -606 & -753 & -740 & -620 \\
\hline Structural overall balance 3/ & -87 & -104 & -651 & -598 & -671 & -726 & -605 \\
\hline Total Financing & -43 & 46 & 680 & 606 & 753 & 740 & 620 \\
\hline External (net) & 38 & -183 & 7 & -72 & 268 & 236 & -23 \\
\hline Internal (net) & -81 & 228 & 673 & 678 & 485 & 504 & 643 \\
\hline \multicolumn{8}{|l|}{ Memorandum Items: } \\
\hline Central government debt & 3,747 & 3,891 & 4,843 & 4,587 & 5,631 & 5,197 & 5,878 \\
\hline External & 773 & 669 & 716 & 610 & 1,009 & 795 & 797 \\
\hline Domestic & 2,973 & 3,222 & 4,127 & 3,977 & 4,622 & 4,402 & 5,081 \\
\hline
\end{tabular}

Sources: Ministry of Finance; and Fund staff estimates.

1/ IMF Country Report No. 10/2.

2/ TUDES are inflation indexed bonds of the central government. The inflation adjustment of principal is not reflected as interest expenditure in the fiscal accounts of the Costa Rican authorities, but is added here to the Fund presentation of the fiscal deficit and public sector debt.

3/ For 2008, excludes one time expense for recapitalization of commercial banks. 
Table 6. Costa Rica: Combined Public Sector Operations 2007-11 1/

(In percent of GDP)

\begin{tabular}{|c|c|c|c|c|c|c|c|}
\hline & \multirow[t]{2}{*}{2007} & \multirow[t]{2}{*}{2008} & \multicolumn{2}{|c|}{2009} & \multicolumn{2}{|c|}{2010} & \multirow{2}{*}{$\begin{array}{r}2011 \\
\text { Proj. }\end{array}$} \\
\hline & & & Prog. 2/ & Prel. & Prog. 2I & Proj. & \\
\hline Revenues & 22.8 & 23.1 & 21.9 & 22.1 & 23.1 & 22.8 & 24.0 \\
\hline Tax revenue & 15.2 & 15.6 & 13.9 & 13.8 & 14.7 & 14.4 & 15.6 \\
\hline Direct taxes & 4.6 & 5.1 & 4.7 & 4.9 & 5.1 & 5.1 & 5.9 \\
\hline Sales tax & 5.9 & 6.0 & 5.0 & 4.9 & 5.3 & 5.1 & 5.6 \\
\hline Excise, customs, and others & 4.8 & 4.6 & 4.3 & 4.0 & 4.3 & 4.2 & 4.1 \\
\hline Nontax revenue & 0.3 & 0.2 & 0.3 & 0.3 & 0.3 & 0.3 & 0.3 \\
\hline Contributions to social security & 6.3 & 6.7 & 7.1 & 7.5 & 7.5 & 7.4 & 7.4 \\
\hline Operating balance of public enterprises & 1.0 & 0.5 & 0.6 & 0.6 & 0.6 & 0.8 & 0.8 \\
\hline Noninterest expenditure & 18.7 & 20.9 & 24.4 & 23.9 & 25.4 & 25.0 & 25.3 \\
\hline Wages and salaries & 7.1 & 7.4 & 9.0 & 8.7 & 9.4 & 9.4 & 9.3 \\
\hline Goods and services & 2.0 & 2.0 & 2.3 & 2.2 & 2.4 & 2.4 & 2.4 \\
\hline Pensions & 4.4 & 4.6 & 5.2 & 5.2 & 5.6 & 5.5 & 5.4 \\
\hline Transfers & 3.2 & 3.8 & 4.7 & 4.7 & 4.8 & 4.7 & 4.7 \\
\hline Central Bank primary losses & 0.0 & -0.2 & 0.0 & 0.1 & 0.1 & 0.1 & 0.1 \\
\hline Net capital expenditure & 2.1 & 3.2 & 3.2 & 2.9 & 3.1 & 2.9 & 3.4 \\
\hline Central Government (incl. capital transfers) & 1.3 & 2.2 & 2.0 & 1.8 & 2.0 & 1.9 & 2.0 \\
\hline Rest of the nonfinancial public sector & 0.8 & 1.0 & 1.3 & 1.1 & 1.1 & 1.1 & 1.4 \\
\hline Primary balance & 4.1 & 2.2 & -2.5 & -1.8 & -2.3 & -2.1 & -1.3 \\
\hline Net interest expenditure & 2.9 & 2.1 & 2.2 & 2.2 & 2.4 & 2.3 & 2.2 \\
\hline Overall Balance & 1.2 & 0.1 & -4.8 & -4.0 & -4.7 & -4.5 & -3.4 \\
\hline Central government & 0.3 & -0.3 & -4.1 & -3.6 & -4.1 & -4.0 & -3.0 \\
\hline of which : Adjustment for TUDES 3/ & -0.3 & -0.5 & -0.2 & -0.2 & -0.3 & -0.3 & -0.2 \\
\hline Social security agency & 1.2 & 0.6 & 0.2 & 0.5 & 0.1 & 0.0 & 0.1 \\
\hline of which : Adjus tment for TUDES 3/ & 0.3 & 0.2 & 0.1 & 0.1 & 0.1 & 0.1 & 0.1 \\
\hline Other public enterprises and entities & 0.4 & 0.0 & -0.1 & -0.1 & 0.0 & 0.1 & 0.0 \\
\hline Central bank & -0.7 & -0.2 & -0.8 & -0.8 & -0.6 & -0.6 & -0.5 \\
\hline Total Financing & -1.2 & -0.1 & 4.8 & 4.0 & 4.7 & 4.5 & 3.4 \\
\hline External & 0.3 & -1.1 & -0.1 & -0.1 & 1.3 & 0.8 & -0.3 \\
\hline Internal & -1.5 & 0.9 & 4.9 & 4.1 & 3.3 & 3.7 & 3.7 \\
\hline \multicolumn{8}{|l|}{ Memorandum items: } \\
\hline Total combined public sector debt & 43.2 & 35.7 & 39.9 & 37.9 & 41.6 & 37.9 & 38.2 \\
\hline External & 7.8 & 5.5 & 5.5 & 4.9 & 6.7 & 5.3 & 4.8 \\
\hline Domestic & 35.4 & 30.2 & 34.4 & 33.0 & 34.9 & 32.7 & 33.5 \\
\hline
\end{tabular}

Sources: Ministry of Finance; and Fund staff estimates.

$1 /$ Combined public sector $=$ Central government + Central bank + Other public enterprises and entities, 2/ IMF Country Report No. 10/2 excluding Instituto de Electricidad (ICE).

$3 /$ TUDES are inflation indexed bonds of the central government. The inflation adjustment of principal is not reflected as interest expenditure in the fiscal accounts of the Costa Rican authorities, but is included in the Fund presentation of the fiscal deficit and public sector debt. 
Table 7. Costa Rica: Combined Public Sector Operations 2007-11 1/

(In billions of colones)

\begin{tabular}{|c|c|c|c|c|c|c|c|}
\hline & \multirow[t]{2}{*}{2007} & \multirow[t]{2}{*}{2008} & \multicolumn{2}{|c|}{2009} & \multicolumn{2}{|c|}{2010} & \multirow{2}{*}{$\begin{array}{r}2011 \\
\text { Proj. }\end{array}$} \\
\hline & & & Prog. 2/ & Prel. & Prog. 2/ & Proj. & \\
\hline Revenues & 3,098 & 3,632 & 3,662 & 3,714 & 4,204 & 4,242 & 4,913 \\
\hline Tax revenue & 2,067 & 2,453 & 2,333 & 2,321 & 2,673 & 2,677 & 3,190 \\
\hline Direct taxes & 622 & 801 & 786 & 820 & 936 & 948 & 1,206 \\
\hline Sales tax & 798 & 937 & 835 & 831 & 960 & 950 & 1,149 \\
\hline Excise, customs, and others & 647 & 715 & 712 & 670 & 778 & 778 & 834 \\
\hline Nontax revenue & 38 & 37 & 44 & 42 & 51 & 49 & 54 \\
\hline Contributions to social security & 855 & 1,057 & 1,190 & 1,252 & 1,371 & 1,371 & 1,510 \\
\hline Operating balance of public enterprises & 139 & 85 & 96 & 99 & 108 & 145 & 160 \\
\hline Noninterest expenditure & 2,547 & 3,279 & 4,088 & 4,018 & 4,618 & 4,634 & 5,170 \\
\hline Wages and salaries & 959 & 1,165 & 1,501 & 1,469 & 1,717 & 1,745 & 1,904 \\
\hline Goods and services & 266 & 321 & 392 & 373 & 439 & 437 & 481 \\
\hline Pensions & 597 & 719 & 877 & 876 & 1,011 & 1,016 & 1,114 \\
\hline Transfers & 430 & 596 & 781 & 787 & 878 & 879 & 968 \\
\hline Central Bank primary losses & 5 & -27 & -2 & 18 & 13 & 13 & 15 \\
\hline Net capital expenditure & 290 & 505 & 539 & 495 & 560 & 544 & 688 \\
\hline Central government (incl. capital transfers) & 180 & 344 & 329 & 306 & 360 & 344 & 400 \\
\hline Rest of the nonfinancial public sector & 110 & 161 & 210 & 190 & 200 & 199 & 289 \\
\hline Primary balance & 552 & 353 & -426 & -304 & -414 & -392 & -257 \\
\hline Net interest expenditure & 388 & 331 & 370 & 369 & 433 & 435 & 444 \\
\hline Overall Balance & 164 & 22 & -796 & -673 & -847 & -827 & -701 \\
\hline Central government & 43 & -46 & -680 & -606 & -753 & -740 & -620 \\
\hline of which : Adjus tment for TUDES 3/ & -35 & -75 & -41 & -33 & -60 & -52 & -51 \\
\hline Social security agency & 160 & 101 & 36 & 82 & 10 & 7 & 20 \\
\hline of which : Adjus tment for TUDES 3/ & 37 & 34 & 19 & 15 & 27 & 24 & 23 \\
\hline Other public enterprises and entities & 57 & -4 & -25 & -11 & 6 & 16 & 0 \\
\hline Central bank & -96 & -29 & -127 & -138 & -110 & -110 & -101 \\
\hline Total Financing & -164 & -22 & 796 & 673 & 847 & 827 & 701 \\
\hline External & 36 & -170 & -18 & -19 & 241 & 148 & -57 \\
\hline Internal & -200 & 147 & 814 & 693 & 606 & 679 & 758 \\
\hline \multicolumn{8}{|l|}{ Memorandum items: } \\
\hline Total combined public sector debt & 5,871 & 5,602 & 6,681 & 6,368 & 7,569 & 7,047 & 7,816 \\
\hline External & 1,063 & 861 & 921 & 831 & 1,220 & 975 & 973 \\
\hline Domestic & 4,808 & 4,740 & 5,760 & 5,537 & 6,349 & 6,072 & 6,843 \\
\hline
\end{tabular}

Sources: Ministry of Finance; and Fund staff estimates.

$1 /$ Combined public sector $=$ Central government + Central bank + Other public enterprises and entities excluding Instituto de Electricidad (ICE).

2/ IMF Country Report No. 10/2.

3/ TUDES are inflation indexed bonds of the central government. The inflation adjustment of principal is not reflected as interest expenditure in the fiscal accounts of the Costa Rican authorities, but is included in the Fund presentation of the fiscal deficit and public sector debt. 
Table 8. Costa Rica: Monetary Survey 2007-11

(In billions of colones, unless otherwise indicated)

\begin{tabular}{|c|c|c|c|c|c|c|c|}
\hline & \multirow[t]{2}{*}{2007} & \multirow[t]{2}{*}{2008} & \multicolumn{2}{|c|}{2009} & \multicolumn{2}{|c|}{2010} & \multirow{2}{*}{$\frac{2011}{\text { Proj. }}$} \\
\hline & & & Prog. 1/ & Prel. & Prog. 1/ & Proj. & \\
\hline \multicolumn{8}{|l|}{ Central Bank } \\
\hline Net foreign assets & 2,125 & 2,186 & 2,476 & 2,420 & 2,641 & 2,400 & 2,591 \\
\hline $\begin{array}{c}\text { Net international reserves } \\
\text { (In millions of US\$) }\end{array}$ & $\begin{array}{l}2,037 \\
4,114\end{array}$ & $\begin{array}{l}2,090 \\
3,799\end{array}$ & $\begin{array}{l}2,338 \\
4,004\end{array}$ & $\begin{array}{l}2,272 \\
4,066\end{array}$ & $\begin{array}{l}2,487 \\
4,104\end{array}$ & $\begin{array}{l}2,218 \\
4,266\end{array}$ & $\begin{array}{l}2,400 \\
4,466\end{array}$ \\
\hline $\begin{array}{l}\text { Net domestic assets } \\
\text { Net domestic credit }\end{array}$ & $\begin{array}{r}-1,097 \\
-429\end{array}$ & $\begin{array}{r}-1,035 \\
-547\end{array}$ & $\begin{array}{r}-1,236 \\
-833\end{array}$ & $\begin{array}{r}-1,210 \\
-790\end{array}$ & $\begin{array}{r}-1,281 \\
-903\end{array}$ & $\begin{array}{r}-1,103 \\
-820\end{array}$ & $\begin{array}{r}-1,159 \\
-861\end{array}$ \\
\hline Credit to the nonfinancial public sector & -61 & -20 & -92 & -50 & -74 & -32 & -17 \\
\hline Credit to other depository corporations (net & -380 & -525 & -735 & -734 & -823 & -781 & -837 \\
\hline Credit to other financial corporations (net) & 2 & 0 & -3 & -4 & -4 & -4 & -5 \\
\hline Credit to the private sector (net) & 10 & -2 & -2 & -2 & -2 & -2 & -2 \\
\hline Capital account (-) & 1,182 & 1,219 & 1,358 & 1,266 & 1,468 & 1,339 & 1,383 \\
\hline Other items net (-) & -8 & -254 & -356 & -285 & -492 & -88 & -172 \\
\hline Monetary stabilization bonds (-) & $-1,842$ & $-1,453$ & $-1,405$ & $-1,400$ & $-1,355$ & $-1,534$ & $-1,509$ \\
\hline Monetary base & 1,028 & 1,151 & 1,240 & 1,210 & 1,360 & 1,297 & 1,431 \\
\hline Currency & 546 & 575 & 623 & 613 & 662 & 664 & 713 \\
\hline Required reserves & 482 & 576 & 616 & 597 & 698 & 632 & 719 \\
\hline \multicolumn{8}{|l|}{ Other Depository Institutions } \\
\hline Net foreign assets & -347 & -473 & 8 & -20 & 8 & 57 & -2 \\
\hline Net domestic assets & 6,250 & 7,796 & 8,739 & 8,138 & 10,080 & 9,526 & 10,871 \\
\hline Net domestic credit & 8,097 & 10,064 & 11,117 & 11,097 & 12,506 & 11,844 & 13,043 \\
\hline Credit to nonfinancial public sector (net) & 338 & 316 & 506 & 586 & 626 & 666 & 491 \\
\hline Credit to the private sector & 6,014 & 7,926 & 8,367 & 8,281 & 9,460 & 8,864 & 10,109 \\
\hline Credit to financial corporations (net) & 1,746 & 1,823 & 2,243 & 2,231 & 2,419 & 2,314 & 2,443 \\
\hline Capital account & 1,237 & 1,597 & 1,653 & 1,829 & 1,736 & 1,819 & 1,910 \\
\hline Other items (net) & -609 & -671 & -724 & $-1,129$ & -690 & -499 & -262 \\
\hline Liabilities & 5,904 & 7,323 & 8,747 & 8,118 & 10,088 & 9,582 & 10,869 \\
\hline National currency & 3,502 & 3,950 & 4,501 & 4,308 & 5,121 & 4,987 & 5,883 \\
\hline Foreign currency & 2,402 & 3,373 & 4,246 & 3,810 & 4,967 & 4,596 & 4,986 \\
\hline \multicolumn{8}{|l|}{ Financial System } \\
\hline Net foreign assets & 1,778 & 1,713 & 2,484 & 2,400 & 2,649 & 2,457 & 2,589 \\
\hline Net domestic assets & 5,645 & 6,997 & 7,640 & 7,055 & 8,794 & 8,670 & 9,859 \\
\hline Net domestic credit & 6,291 & 8,221 & 8,781 & 8,816 & 10,013 & 9,498 & 10,583 \\
\hline Capital account & 55 & 378 & 295 & 564 & 268 & 480 & 527 \\
\hline Other items (net) & -590 & -847 & -846 & $-1,197$ & -951 & -348 & -196 \\
\hline Broad money (M4) & 7,423 & 8,709 & 10,123 & 9,455 & 11,443 & 11,126 & 12,448 \\
\hline \multicolumn{8}{|l|}{ Memorandum Items } \\
\hline & \multicolumn{7}{|c|}{ (Percent changes) } \\
\hline Monetary base & 33.0 & 11.9 & 7.7 & 5.1 & 9.7 & 7.2 & 10.4 \\
\hline Broad money (M4) & 16.3 & 17.3 & 16.2 & 8.6 & 13.0 & 17.7 & 11.9 \\
\hline Credit to the private sector (National Currency) & 45.2 & 27.1 & 4.8 & 8.3 & 12.2 & 9.1 & 15.4 \\
\hline \multirow[t]{2}{*}{ Credit to the private sector (Foreign Currency) } & 30.0 & 38.2 & 6.6 & -0.3 & 14.1 & 4.2 & 12.1 \\
\hline & \multicolumn{7}{|c|}{ (In percent of GDP) } \\
\hline Monetary base & 7.6 & 7.3 & 7.4 & 7.2 & 7.5 & 7.0 & 7.0 \\
\hline Broad money (M4) & 54.6 & 55.4 & 60.4 & 56.3 & 63.0 & 59.9 & 60.9 \\
\hline Credit to the private sector (National Currency) & 25.5 & 28.0 & 27.5 & 28.4 & 28.5 & 28.0 & 29.4 \\
\hline Credit to the private sector (Foreign Currency) & 18.8 & 22.4 & 22.4 & 20.9 & 23.6 & 19.7 & 20.1 \\
\hline
\end{tabular}

Sources: BCCR; and Fund staff calculations.

1/ IMF Country Report No. 10/2. 
Table 9. External Financing Requirements and Sources 2007-11

(In millions of U.S. dollars)

\begin{tabular}{|c|c|c|c|c|c|c|c|}
\hline & \multirow[t]{2}{*}{2007} & \multirow[t]{2}{*}{2008} & \multicolumn{2}{|c|}{2009} & \multicolumn{2}{|c|}{2010} & \multirow{2}{*}{$\begin{array}{r}2011 \\
\text { Proj. }\end{array}$} \\
\hline & & & Prog. 1/ & Prel. & Prog. 1/ & Proj. & \\
\hline Gross Financing Requirements & 5,324 & 6,681 & 5,664 & 4,920 & 5,300 & 4,831 & 5,581 \\
\hline Current account deficit (exc. official transfers) & 1,646 & 2,754 & 890 & 634 & 1,384 & 1,468 & 1,751 \\
\hline Debt amortization 2/ & 2,838 & 4,242 & 4,774 & 4,223 & 3,817 & 3,163 & 3,631 \\
\hline Medium and long-term debt & 483 & 1,018 & 779 & 615 & 559 & 812 & 1,093 \\
\hline Public sector & 237 & 726 & 458 & 295 & 200 & 453 & 773 \\
\hline Private sector & 246 & 292 & 321 & 321 & 358 & 359 & 320 \\
\hline Short-term debt $3 /$ & 2,356 & 3,224 & 3,995 & 3,608 & 3,258 & 2,352 & 2,537 \\
\hline Repayment of arrears & 0 & 0 & 0 & 0 & 0 & 0 & 0 \\
\hline Gross reserves accumulation & 839 & -315 & 0 & 62 & 100 & 200 & 200 \\
\hline Available Financing & 5,324 & 6,681 & 5,664 & 4,920 & 5,300 & 4,831 & 5,581 \\
\hline Foreign direct investment (net) & 1,634 & 2,015 & 1,201 & 1,316 & 1,295 & 1,430 & 1,734 \\
\hline Debt financing & 4,072 & 4,866 & 4,423 & 3,574 & 4,006 & 3,356 & 3,847 \\
\hline Medium and long-term financing & 848 & 1,258 & 1,165 & 1,222 & 802 & 819 & 1,005 \\
\hline Public sector & 236 & 737 & 547 & 596 & 655 & 769 & 682 \\
\hline Private sector & 612 & 521 & 618 & 625 & 147 & 50 & 323 \\
\hline Short-term financing & 3,224 & 3,608 & 3,258 & 2,352 & 3,204 & 2,537 & 2,842 \\
\hline Other flows $4 /$ & -382 & -201 & 39 & 30 & 0 & 45 & 0 \\
\hline \multicolumn{8}{|l|}{ Memorandum Item: } \\
\hline Gross financing requirement (in percent of GDP) & 20.2 & 22.4 & 19.3 & 16.8 & 17.4 & 13.7 & 14.4 \\
\hline
\end{tabular}

Sources: Authorities; and Fund staff estimates.

1/ IMF Country Report No. 10/2.

2/ Excluding the IMF.

3 / Original maturity of less than 1 year. Stock at the end of the previous period.

4 / Includes all other net financial flows, and errors and omissions. 
Table 10. Costa Rica: Indicators of External Vulnerability 2007-11

\begin{tabular}{|c|c|c|c|c|c|}
\hline & \multirow[b]{2}{*}{2007} & \multirow[b]{2}{*}{2008} & \multirow[b]{2}{*}{2009} & \multicolumn{2}{|c|}{ Proj. } \\
\hline & & & & 2010 & 2011 \\
\hline Merchandise exports (percent change) $1 /$ & 12.8 & 13.8 & -9.3 & 9.0 & 6.3 \\
\hline Merchandise imports (percent change) $1 /$ & 23.2 & 24.4 & -26.8 & 18.4 & 9.6 \\
\hline Terms of trade (percent change) & -4.0 & -3.5 & 5.8 & -1.2 & -1.5 \\
\hline Current account balance (in percent of GDP) & -6.3 & -9.2 & -2.2 & -4.2 & -4.5 \\
\hline Central bank net international reserves (in US\$ millions) & $4,113.7$ & $3,799.1$ & $4,066.3$ & $4,266.3$ & $4,466.3$ \\
\hline -In months of next year's imports of nonmaquila goods and services & 3.8 & 4.6 & 4.2 & 4.1 & 4.0 \\
\hline -In percent of base money & 199.3 & 183.3 & 189.9 & 171.1 & 167.7 \\
\hline -In percent of $\mathrm{M} 4$ & 27.6 & 24.2 & 24.3 & 19.9 & 19.3 \\
\hline -In percent of deposits in foreign currency & 85.3 & 62.6 & 60.3 & 48.3 & 48.1 \\
\hline -In percent of short-term external debt $2 /$ & 97.0 & 90.0 & 128.5 & 117.5 & 122.8 \\
\hline Public external debt service (in percent of GDP) & 1.6 & 3.0 & 1.6 & 1.9 & 2.4 \\
\hline External debt (in percent of GDP) & 31.7 & 29.7 & 27.4 & 23.3 & 21.8 \\
\hline External debt (in percent of exports) & 64.9 & 64.6 & 63.5 & 61.0 & 58.7 \\
\hline REER appreciation (+) & 2.8 & 5.3 & 1.7 & $\ldots$ & $\ldots$ \\
\hline
\end{tabular}

Sources: Central Bank of Costa Rica; and Fund staff estimates.

$1 /$ In value terms, excludes goods for processing.

2/ Public and private sector external debt on remaining maturity. Includes trade credits. 
Table 11. Costa Rica: Medium-Term Framework 2007-15

(Annual percentage change; unless otherwise indicated)

\begin{tabular}{|c|c|c|c|c|c|c|c|c|c|}
\hline & \multirow[b]{2}{*}{2007} & \multirow[b]{2}{*}{2008} & \multirow[b]{2}{*}{2009} & \multicolumn{6}{|c|}{ Projection } \\
\hline & & & & 2010 & 2011 & 2012 & 2013 & 2014 & 2015 \\
\hline Real GDP & 7.9 & 2.8 & -1.1 & 3.8 & 4.2 & 4.4 & 4.5 & 4.4 & 4.4 \\
\hline Consumption & 6.9 & 3.9 & 2.1 & 3.7 & 4.0 & 3.9 & 4.0 & 3.9 & 3.9 \\
\hline Private consumption & 7.5 & 3.9 & 1.6 & 3.6 & 4.0 & 4.0 & 4.1 & 4.0 & 4.0 \\
\hline Government consumption & 2.3 & 4.3 & 6.4 & 4.6 & 3.4 & 3.2 & 3.4 & 3.3 & 3.2 \\
\hline Gross domestic investment & -1.2 & 18.1 & -30.0 & 16.3 & 10.0 & 5.3 & 5.6 & 5.1 & 5.7 \\
\hline Fixed capital formation & 18.2 & 9.9 & -12.1 & 4.1 & 8.2 & 6.3 & 6.5 & 5.7 & 5.7 \\
\hline Exports of goods and nonfactor services & 9.9 & -1.7 & -6.4 & 4.6 & 5.3 & 4.7 & 5.0 & 5.2 & 5.1 \\
\hline Imports of goods and nonfactor services & 4.3 & 6.3 & -16.7 & 9.8 & 7.6 & 4.5 & 4.9 & 4.8 & 5.0 \\
\hline Consumption (contribution to growth) & 4.9 & 2.8 & 1.6 & 2.8 & 2.9 & 2.9 & 2.9 & 2.9 & 2.8 \\
\hline Investment (contribution to growth) & 3.8 & 2.2 & -2.9 & 0.9 & 1.8 & 1.4 & 1.5 & 1.3 & 1.3 \\
\hline Inventories (contribution to growth) & -4.0 & 2.1 & -5.4 & 2.3 & 0.4 & -0.2 & -0.2 & -0.1 & 0.0 \\
\hline Net exports (contribution to growth) & 3.3 & -4.3 & 5.6 & -2.1 & -0.9 & 0.2 & 0.2 & 0.3 & 0.2 \\
\hline \multicolumn{10}{|l|}{ Investment and savings (in percent of GDP) } \\
\hline Savings & 24.7 & 27.5 & 13.8 & 16.9 & 18.4 & 19.1 & 19.7 & 20.1 & 20.5 \\
\hline National savings & 18.4 & 18.3 & 11.6 & 12.7 & 13.9 & 14.5 & 15.0 & 15.4 & 15.7 \\
\hline External savings $1 /$ & 6.3 & 9.2 & 2.2 & 4.2 & 4.5 & 4.7 & 4.7 & 4.8 & 4.8 \\
\hline Gross domestic investment & 24.7 & 27.5 & 13.8 & 16.9 & 18.4 & 19.1 & 19.7 & 20.1 & 20.5 \\
\hline Private sector & 18.6 & 19.3 & 17.0 & 15.6 & 15.6 & 15.7 & 15.8 & 15.9 & 16.1 \\
\hline Public sector & 3.2 & 4.0 & 3.8 & 3.8 & 4.2 & 4.2 & 4.3 & 4.3 & 4.4 \\
\hline Inventory changes & 2.9 & 4.2 & -7.0 & -2.5 & -1.3 & -0.8 & -0.4 & 0.0 & 0.0 \\
\hline \multicolumn{10}{|l|}{ Balance of payments (in percent of GDP) } \\
\hline Current account balance & -6.3 & -9.2 & -2.2 & -4.2 & -4.5 & -4.7 & -4.7 & -4.8 & -4.8 \\
\hline Trade balance & -11.3 & -16.8 & -6.9 & -8.7 & -9.8 & -9.9 & -10.0 & -10.1 & -10.2 \\
\hline Services & 6.6 & 7.5 & 7.4 & 6.4 & 6.4 & 6.4 & 6.5 & 6.7 & 7.0 \\
\hline Income & -3.3 & -1.5 & -3.7 & -2.9 & -2.1 & -2.1 & -2.0 & -2.2 & -2.4 \\
\hline Current transfers & 1.8 & 1.5 & 1.1 & 1.0 & 1.0 & 1.0 & 0.9 & 0.9 & 0.9 \\
\hline Financial and capital account & 8.8 & 8.1 & 1.8 & 4.7 & 5.0 & 5.1 & 5.1 & 5.2 & 5.2 \\
\hline Direct investment & 6.2 & 6.8 & 4.5 & 4.1 & 4.5 & 4.5 & 4.5 & 4.6 & 4.7 \\
\hline Capital flows & 2.5 & 1.3 & -2.8 & 0.7 & 0.6 & 0.6 & 0.6 & 0.6 & 0.5 \\
\hline Public sector & 0.0 & 0.0 & 1.0 & 0.9 & -0.2 & 0.2 & 0.2 & 0.2 & 0.2 \\
\hline Private net capital & 2.5 & 1.3 & -3.8 & -0.2 & 0.8 & 0.4 & 0.4 & 0.3 & 0.3 \\
\hline Errors and omissions & 0.6 & 0.1 & 0.6 & 0.0 & 0.0 & 0.0 & 0.0 & 0.0 & 0.0 \\
\hline Change in net reserves (increase -) & -3.2 & 1.1 & -0.2 & -0.6 & -0.5 & -0.5 & -0.5 & -0.4 & -0.4 \\
\hline \multicolumn{10}{|l|}{ Memorandum items: } \\
\hline GDP deflator & 9.4 & 12.3 & 8.1 & 6.5 & 5.7 & 4.8 & 4.5 & 4.3 & 3.9 \\
\hline CPI (avg) & 9.4 & 13.4 & 7.8 & 5.1 & 5.5 & 4.7 & 4.5 & 4.2 & 4.0 \\
\hline CPI (eop) & 10.8 & 13.9 & 4.0 & 6.0 & 5.0 & 4.5 & 4.5 & 4.0 & 4.0 \\
\hline Net international reserves (millions of US\$) & 4,114 & 3,799 & 4,066 & 4,266 & 4,466 & 4,666 & 4,866 & 5,066 & 5,266 \\
\hline
\end{tabular}

Sources: Central Bank of Costa Rica; and Fund staff estimates.

1/ External current account deficit. 
San José, May 12, 2010

Mr. Dominique Strauss-Kahn

Managing Director

International Monetary Fund

Washington, D.C.

Dear Mr. Strauss-Kahn:

1. The purpose of this letter is to inform you about the progress in the implementation of our economic program, which is being supported under the Stand-By Arrangement (SBA) approved by the IMF Executive Board on April 10, 2009.

2. Macroeconomic developments have been more favorable than projections made at the time of the second program review last November. The broad-based recovery of the Costa Rican economy is firmly underway and output growth forecast for 2010 has been revised upward to 3.8 percent. Inflation is likely to stay within the central bank's year-end target range of 4-6 percent in 2010. The external current account deficit declined to 2.2 percent of GDP in 2009. The fiscal outturn was better than envisaged, with the deficit of the combined public sector in 20090.8 percentage point of GDP lower than projected. In addition, the banking sector remains sound, and the deterioration in prudential indicators observed in mid2009 has begun to reverse.

3. Performance against the program targets remains strong. All quantitative performance criteria for end-December 2009 and end-March 2010 were met, most with significant margins. Observance of the two end-December structural benchmarks (submission to parliament of draft laws to create a limited deposit insurance scheme and to strengthen the bank resolution framework) were delayed by a decision to allow further feedback from stakeholders but have now been completed.

4. In light of this performance and our continued commitment to the program, we request the completion of the third and final review under the SBA. We also request that the availability date of the fifth (and final) purchase under the arrangement be brought forward to become available following the completion of the review scheduled for May 28, 2010. Our intention remains to treat the arrangement as precautionary.

5. We remain committed to the broad macroeconomic policy agenda set out in previous Letters of Intent as the program comes to an end in July 2010. Going forward, we intend to continue the productive and fruitful dialogue we have had with the Fund. 
Sincerely yours,

$\underline{\mathrm{s} /}$

Fernando Herrero

Minister of Finance /s/

Francisco de Paula Gutiérrez

President, Central Bank of Costa Rica 


\section{INTERNATIONAL MONETARY FUND \\ EXTERNAL \\ RELATIONS \\ DEPARTMENT}

Press Release No. 10/222

International Monetary Fund

FOR IMMEDIATE RELEASE

Washington, D.C. 20431 USA

June 1,2010

\section{IMF Executive Board Completes Final Review Under Stand-By Arrangement with Costa Rica}

The Executive Board of the International Monetary Fund (IMF) completed on May 28, 2010 the third and final review of Costa Rica's economic performance under a program supported by a 15-month Stand-By Arrangement (SBA) approved on April 10, 2009 (see Press Release 09/124). The authorities have indicated that they will continue to treat the arrangement as precautionary.

The completion of the third and final review enables Costa Rica to purchase an additional amount equivalent to SDR 41.025 million (about US\$60.5 million), if needed. The review brings the total amount available for purchase to SDR 492.3 million (about US\$725.8 million).

Following the Executive Board's discussion on Costa Rica, Mr. Murilo Portugal, Deputy Managing Director and Acting Chair, stated:

"Costa Rica's economic recovery is picking up speed, supported by rising consumer and business confidence. The authorities' comprehensive response to the global crisis, supported by the Fund program, created a solid basis for the recovery. The external payments position has strengthened, and the exchange rate has fluctuated in the lower part of the band. The strong prospects for domestic demand create upside risks to the growth outlook and underscore the need to rebalance the macroeconomic policy mix.

"Performance under the Stand-By Arrangement with the Fund has been commendable. All quantitative performance criteria for end-December 2009 and end-March 2010 were met, and the authorities have continued to treat the arrangement as precautionary.

"The expansionary fiscal stance of 2009 was instrumental in softening the impact of the global crisis on economic activity. As the recovery becomes self-sustained, it will be important to start withdrawing the fiscal stimulus during 2010 and aim for considerable fiscal consolidation starting in 2011. 
"Inflation fell to low single digits during 2009, and core inflation remains stable. However, inflation expectations remain above the central bank's end-year inflation target, partly due to the strong prospects for domestic demand. It is important that the central bank stands ready to tighten monetary policy if this situation persists. Accelerating the transition to inflation targeting and greater exchange rate flexibility is also advisable.

"The banking sector remains sound, and the modest deterioration in prudential indicators observed in 2009 has started to abate. Further progress in the financial sector reform, including passage of legislation to strengthen the financial sector safety net, recapitalize the central bank, and enable consolidated supervision, would contribute to strengthening the system's resilience," Mr. Portugal stated. 
Statement by Mr. Guzmán, Executive Director for Costa Rica

and Mr. Gramajo-Marroquin, Senior Advisor

May 26, 2010:

We thank Staff for a concise and well-written report. Our authorities broadly agree with the Staff's assessment and recommendations.

Regarding performance under the program, all quantitative criteria for end-

December 2009 and end-March 2010 were met, most with significant margins.

Observance of the two end-December structural benchmarks (submission to parliament of draft laws to create a deposit insurance scheme and to strengthen the bank resolution framework) were delayed in order to permit further feedback from stakeholders but have now been completed.

After being elected in February, President Ms. Laura Chinchilla took office on May 8, 2010. The new government is fully committed to maintain macroeconomic stability and to promote structural changes, including strengthening law enforcement and boosting the quality of public education.

Recent Developments. Macroeconomic developments have been better than projections indicated during the second program review. The broad-based recovery of the Costa Rican economy is firmly underway and the output growth forecast for 2010 has been revised upward. Inflation most likely will stay in the upper limit of the Central Bank's year-end target range of 4-6 percent in 2010. Fiscal performance in 2009 was also better than envisaged, with the combined public deficit lower than projected. The banking sector remains sound, and the deterioration in prudential indicators registered in mid2009 has begun to reverse.

Economic Outlook. As mentioned, the outlook for the remaining of 2010 improved with respect to the second program review. Given the faster-than-expected recovery, Staff made an upward revision to the output growth rates projected for 2010 and also for 2011 (to 3.8 percent and 4.2 percent, respectively). The projected end-2010 inflation was revised upward to 6 percent due to recent increases in regulated prices, a higher-thanprojected rise in food and fuel prices, and a stronger domestic demand. Although prospects for external inflows (including FDI) have improved, the external current account deficit is still projected to exceed 4 percent of GDP by end-2010 driven by a strong recovery in imports (reflecting the improvement in domestic demand).

Fiscal Policy. The Central government's deficit at end-2009 was 3.6 percent of GDP ( 0.5 percentage point lower than the program's) while the deficit of the combined public sector was 4 percent of GDP (0.8 percentage point lower than the program's). This better-than- expected performance has to do with expenditure restraint (on wages and investment), and with a larger-than-projected surplus of the social security entity. Tax revenues were consistent with projections, mainly due to the strong performance of import-related taxes. 
The authorities are strongly committed to prudent fiscal management and plan to elaborate a medium-term fiscal strategy in the second semester of 2010 . They also intend to initiate fiscal consolidation in 2011.

Monetary and Exchange Rate Policy. The Authorities are of the view that the Central Bank should focus on consolidating recent gains in low inflation, which could facilitate the gradual adoption of an inflation targeting regime. Despite the recent rise in CPI inflation, which is mainly related to increases in some administered prices, our authorities believe that there is no evidence of underlying price pressures. However, bearing in mind that the improved domestic demand and the increases in commodities' prices, mainly oil, have the potential to generate inflation pressures, the Central Bank will maintain its cautious policy stance and is ready to tighten monetary policy if needed.

The exchange rate has appreciated during the present year, approaching the lower limit of the band; however, it has recently begun to depreciate and has shown more variability. Although during policy discussions Staff suggested either the elimination of the band or a downward shift of the floor, our authorities expressed that both proposals could lead to an abrupt appreciation as occurred in 2008. However, they reiterated their intention to move further towards exchange rate flexibility, which would be consistent with the gradual adoption of an inflation targeting regime.

Financial Sector. Costa Rica's financial system has weathered the global crisis well, while prudential indicators will improve as economic activity takes hold. Moreover, the banking sector remains well capitalized and liquid. Although the intervention of one important institution in the cooperative sector was adopted opportunely, that situation made evident some limitations in the current resolution framework. In that sense, our authorities are of the view that adopting the deposit insurance and the resolution framework, included in the draft laws sent to the Legislative Assembly, would help to improve the resilience and confidence of the financial sector.

Finally, our authorities believe that the ongoing policies are adequate to meet their social and economic objectives, those that have been effectively supported by the Stand-By arrangement. The authorities reiterate that they will continue treating the arrangement as precautionary. Looking ahead, our authorities intend to continue the close and fruitful dialogue with the Fund. 